\title{
PENERAPAN MODELPEMBELAJARAN KOOPERATIFTIPE GROUP INVESTIGATION (GI) DALAM MENINGKATKAN KOMPETENSI MATEMATIKA SISWA
}

\author{
Dewi Sartika $^{* 1}$ dan Dewi Siliviana ${ }^{1}$ \\ ${ }^{1}$ Program Studi Pendidikan Matematika, STKIP Bima \\ *Email korespondensi: dewisartika_mat@stkipbima.ac.id
}

\begin{abstract}
ABSTRAK
Tujuan dari penelitian ini adalah penerapan model pembelajaran group investigation dalam meningkatkan kompetensi matematika siswa kelas VIIIA di SMP Negeri 2 Manggelewa tahun pelajaran 2017/2018. Jenis penelitian adalah penelitian tindakan kelas (PTK) yang tiap siklus terdiri dari 4 tahap yaitu perencanaan, pelaksanaan, evaluasi/observasi san refleksi. Subjek dalam penelitian ini yaitu siswa kelas VIII.A dengan jumlah siswa 35. Instrumen penelitian yang digunakan dalam penelitian ini adalah lembar observasi dan tes evaluasi berbentuk essay tiap akhir siklus. Indikator keberhasilan siswa dalam penelitian ini adalahKetuntasan klasikal belajar siswa $\geq 85 \%$ yang memperoleh nilai minimal 65 untuk mengetahui kompetensi matematika siswa dan aktivitas siswa minimal berkategori aktif. Hasil penelitian yang didapat adalah sebagai berikut: Siklus I; nilai rata-rata kompetensi belajar siswa 66,3 dengan persentase ketuntasan belajar sebesar 71,4\%. Sedangkan pada siklus II; nilai rata-rata hasil belajar siswa menjadi 70,3 dengan persentase ketuntasan belajar siswa mengalami peningkatan sebesar 7,6\% menjadi $89 \%$. Pada aktivitas belajar siswa siklus pertama kategori cukup aktif dan aktivitas belajar siswa pada siklus kedua berkategori aktif . Disimpulkan bahwa penerapan model pembelajaran kooperatif tipe group invetigation dapat meningkatkan kompetensimatematika siswa kelas VIIIA di SMP Negeri 2 Manggelewa tahun pelajaran 2017/2018.
\end{abstract}

Kata Kunci: pembelajaran kooperatif, group investigation, kompetensi matematika

\begin{abstract}
The purpose of this study is the application model of the group investigation learning in improving the mathematical competencies in class VIIIA students at SMP Negeri 2 Manggelewa 2017/2018 school year. The research of class action research (PTK) which each cycle consists of 4 stages, planning, implementation, evaluation / observation and reflection. The subjects is VIII.A students with 35 students. The research instruments used in this study of observation and evaluation tests in essays at the 5 end of each cycle. The indicator of student success in this study is the classic learning completeness of students $285 \%$, a minimum score of 65 to find out students' mathematical competencies and student activities are at least active category. The results of the research obtained are as follows: Cycle I; the
\end{abstract}


average value of student learning competence is 66.3 with a percentage of learning completeness of $71.4 \%$. While in cycle II; the average value of student learning outcomes becomes 70.3 with the percentage of student learning completeness increased by $7.6 \%$ to $89 \%$. In the learning activities of the first cycle students the category is quite active and the learning activities of students in the second cycle are categorized as active. It was concluded that the application of cooperative learning models of investment group type could improve the competency of the mathematics of VIIIA grade students in SMP Negeri 2 Manggelewa in the academic year 2017/2018.

Keywords : Cooperative Learning, Group Investigation, Competency Mathematics

\section{PENDAHULUAN}

Berdasarkan fungsi dan tujuan dari pendidikan nasional dituangkan dalam UU Nomor 20 Tahun 2003 tentang sistem pendidikan nasional pasal 3 yaitu "Pendidikan nasional berfungsi mengembangkan kemampuan dan membentuk watak serta peradaban bangsa yang bermartabat dalam rangka mencerdaskan kehidupan bangsa, bertujuan untuk berkembangnya potensi peserta didik agar menjadi manusia yang beriman dan bertakwa kepada Tuhan Yang Maha Esa, berakhlak mulia, sehat, berilmu, cakap, kreatif, mandiri dan menjadi warga Negara yang demokratis serta bertanggung jawab". Tercapainya fungsi dan tujuan pendidikan yang telah dirumuskan dapat diwujudkan melalui lembaga pendidikan. Lembaga pendidikan yang dimaksud adalah sekolah.

Sekolah sebagai salah satu lembaga pendidikan yang mengembang tugas mencerdaskan kehidupan bangsa, untuk selanjutnya berupaya menyelaraskan kualitasnya dengan lembaga pendidikan yang lainnya. Meski upaya itu telah dilakukan namun kenyataannya masih terdapat banyak kekurangan yang harus dibenahi.Oleh karena itu, dituntut peningkatan kualitas pengajaran, agar diperoleh hasil belajar yang lebih optimal sehingga menunjang peningkatan kualitas pendidikan. Hal inimenjadi tugas dan tanggung jawab semua pelaku pendidikan termasuk guru.

Guru sebagai salah satu komponen pendidikan mempunyai peran yang cukup besar mengingat posisi dan peranan guru yang bersentuhan langsung dengan siswa melalui proses belajar mengajar di sekolah. Maka guru dituntut untuk dapat lebihpeka terhadap kondisi atau faktor-faktor yang mempengaruhi rendahnya mutu pendidikan dalam hal ini adalah hasil belajar siswa.Peningkatan kualitas, baik proses maupun hasil pengajaran yang berupakan tugas dan tanggung jawab guru. Maka salah satu upaya yang ditempuh adalah melalui pengajaran yang menekankan kepada cara belajar siswa aktif. 
Pembelajaran matematika masih didominasi oleh penggunaan metode ceramah dan kegiatannya lebih berpusat pada guru. Aktivitas siswa dapat dikatakan hanya mendengarkan penjelasan guru dan mencatat hal-hal yang dianggap penting. Guru menjelaskan matematika lainnya sebatas produk dan sedikit proses. Salah satu penyebabnya adalah padatnya materi yang harus dibahas dan diselesaikan berdasarkan kurikulum yang berlaku.

Pembelajaran matematika merupakan pembelajaran yang diharapkan langsung dengan objek yang sedang dipelajari, belajar menghubungkan pengetahuan antara konsep-konsep, hukum dan teori-teori yang dipelajari agar mereka dapat menghubungkan pengetahuan yang dimiliki dengan cara belajar yang aktif dan kreatif, sehingga siswa benar-benar dapat mengerti apa yang dipelajari, bukan dengan cara transfer ilmu pengetahuan yang hanya menjelaskan informasi kedalam benak siswa. Untuk itu telah banyak dikembangkan oleh para pemerhati pendidikan sebagai model pelajaran agar proses pembelajaran matematikan menjadi lebih manarik, dapat merangsang siswa berfikir kreatif dan aktif serta dapat membantu siswa dalam memahami konsep-konsep matematika sehingga tujuan pembelajaran dapat tercapai.

Arends \& Kilcher (2010) menyatakan bahwa"Cooperative learning is a teaching model or strategy that is characterized by cooperative task, goal, and reward structures, and requires students to be actively engaged in discussion, debate, tutoring, and teamwork”. Pembelajaran kooperatif adalah model pembelajaran atau strategi yang dicirikan oleh tugas kelompok, tujuan, dan struktur penghargaan, dan membutuhkan siswa untuk secara aktif terlibat dalam diskusi, debat, latihan, dan kerja sama tim. Sejalan dengan pendapatnya Knight, (2009)“Cooperative learning is learning mediated by students rather than the instructur. In cooperative learning, students work in groups to teach themselves content being covered". Artinya pembelajaran kooperatif adalah mediasi pembelajaran dari siswa yang lebih baik dari guru. Dalam pembelajaran kooperatif, siswa bekerja dalam kelompok untuk mengajar mereka sendiri mencakup isi.

Belajar kelompok dalam sebuah kelas sangat membutuhkan suatu pengaturan dan pengelolaan kelas yang kooperatif, dimana siswa terbentuk dalam kelompok yang heterogen misalnya pintar, tidak pintar, kaya, miskin, beberapa suku, bahasa dan jenis kelamin.

Johnson, Johnson, \& Halubec (2010) menyatakan bahwa pembelajaran kooperatif adalah proses belajar mengajar yang melibatkan penggunaan kelompok-kelompok kecil yang memungkinkan siswa untuk bekerja secara bersama-sama di dalamnya guna memaksimalkan 
pembelajaran mereka sendiri dan pembelajaran satu sama yang lain. Hal ini sejalan dengan pendapatnya Douglas et al. (2009) menyatakan bahwa "cooperative learning as an instructional arrangement that allows two to six student the opportunity to work together on a shared task in order to joinly constuct their knowledge and understanding of the content". Lebih lanjut menurut Arends \& Kilcher, (2010) pembelajaran GI bahwa "In group investigation, students are actively engaged in planning and carrying out investigations and presenting their findings to peers and others. Group investigation begins with the teacher providing a stimulus or problem situation. Students then define more precisely the problem to be investigated, determine the roles required to conduct the investigation, organize themselves to collect information, analyze the data collected, prepare and present a report, and evaluate the results of their work and the processes they used".

Dalam investigasi kelompok, siswa secara aktif terlibat dalam perencanaan dan pelaksanaan penyelidikan dan menyajikan temuan mereka kepada rekan dan lain-lain. investigasi Grup dimulai dengan guru menyediakan situasi stimulus atau masalah. Siswa kemudian mendefinisikan lebih tepat masalah yang akan diteliti, menentukan peran yang diperlukan untuk melakukan investigasi, mengorganisir diri untuk mengumpulkan informasi, menganalisa data yang dikumpulkan, mempersiapkan dan menyajikan laporan, dan mengevaluasi hasil kerja mereka dan proses yang mereka gunakan.

Dalam melaksanakan tugas investigasi siswa dapat mengumpulkan informasi, menganalisis, dan membuat simpulan, setiap anggota kelompok berkontribusi untuk usahausaha yang dilakukan kelompoknya, dan saling bertukar pikiran, berdiskusi, mengklarifikasi, dan mensintesis semua gagasan, sedangkan dalam menyiapkan laporan akhir, aktifitas yang dilakukan siswa adalah anggota kelompok menentukan pesan-pesan esensial dari pekerjaan mereka, anggota kelompok merencanakan apa yang akan mereka laporkan dan bagaimana membuat presentasi, wakil-wakil kelompok membentuk sebuah tim untuk mengkoordinasikan rencana presentasi. Dalam mempresentasikan laporan akhir, presentasi harus dapat melibatkan pendengarnya secara aktif dan pendengar menevaluasi berdasrakan kriteria yang telah ditentukan sebelumnya, sedangakan pada tahap evaluasi, siswa saling memberikan umpan balik, kolaborasi guru dan murid dalam menevaluasi pembelajaran dan penilaian atas pembelajaran harus mengevaluasi pemikiran yang paling tinggi.

\section{METODE PENELITIAN}


Adapun jenis penelitian adalah Penelitian Tindakan Kelas (PTK). Penelitian tindakan merupakan suatu pencarian sistematik yang dilaksanakan oleh para pelaksana program dalam kegiatannya sendiri (guru), dalam mengumpulkan data tentang pelaksanaan kegiatan, keberhasilan dan hambatan yang dihadapi, untuk kemudian menyusun rencana dan melakukan kegiatan-kegiatan penyempurnaan. Penelitian tindakan kelas memiliki siklus yang terdiri dari 4 tahap yaitu perencanaan, pelaksanaan, evaluasi/observasi dan refleksi. Instrumen penelitian yang digunakan untuk mengukur kompetensi matematika siswa adalah soal essay 5 nomor dan lembar observasi aktivitas siswa dan aktivitas guru. Indikator keberhasilan dalam penelitian ini adalah siswa mendapat nilai minimal 65 dan mencapai standar ketuntasan secara klasikal minimal 85\%. Aktivitas siswa minimal berkategori aktif dan aktivitas guru minimal berkategori baik.

\section{HASIL DAN PEMBAHASAN}

Penelitian tindakan kelas dimulai dengan siklus I yang terdiri dari 3 kali pertemuan dengan dua kali pertemuan untuk pembelajaran dan satu kali pertemuan untuk evaluasi setiap siklus. Adapun kegiatan siklus I terdiri dari empat kegiatan, yakni perencanaan, tindakan, observasi, dan refleksi. Berdasarkan siklus I, guru akan mengetahui letak keberhasilan dan kegagalan atau hambatan yang dijumpai pada siklus I. Oleh karena itu, guru merumuskan kembali rancangan tindakan untuk siklus II. Kegiatan pada siklus ke II ini dapat berupa kegiatan sebagaimana yang dilakukan pada siklus I, tetapi sudah dilakukan perbaikanperbaikan atau hambatan-hambatan berdasarkan hambatan atau kegagalan yang dijumpai pada siklus I. Hasil penelitian yang didapat adalah sebagai berikut:

Tabel 1. Deskripsi Data Hasil Tes

\begin{tabular}{rccrc}
\hline Siklus & Skor Minimum & Skor Maksimum & Rata-rata & Persentase Ketuntasan \\
\hline I & 50 & 95 & 66,3 & $71,4 \%$ \\
II & 55 & 100 & 70,3 & $89 \%$
\end{tabular}

Siklus I; nilai rata-rata kompetensi belajar siswa 66,3 dengan persentase ketuntasan belajar sebesar 71,4\%. Pada siklus pertama ini peneliti belum mencapai indikator keberhasilan dalam penelitiansehingga dilanjutkan pada siklus yang ke dua. Pada siklus II; nilai rata-rata hasil belajar siswa menjadi 70,3 dengan persentase ketuntasan belajar siswa89\%. Dari siklus I ke siklus II persentase ketuntasan kompetensi belajar siswa mengalami peningkatan sebesar 
7,6\%. Sedangkan pada aktivitas belajar siswa siklus pertama kategori cukup aktif dan aktivitas belajar siswa pada siklus kedua berkategoriaktif. Berdasarkan data yang diperoleh pada saat pelaksanaan tindakan I, dapat diketahui bahwa penggunaan metode kooperatif tipe group investigatin sangat mempengaruhi semangat dan keseriusan siswa dalam upaya memahami materi sistim koordinat yang dijelaskan. Mulai dari tahap presentasi kelas hingga kesimpulan . Hanya saja pada pelaksanaan tindakan I ini, masih terdapat banyak kekurangan-kekurangan antara lain:

1. Pemberian motivasi dan apersepsi yang sangat kurang membuat siswa sedikit bingung dalam menerima materi dengan menerapkan model pembelajaran group investigation

2. Kerjasama antar siswa dalam mengerjakan tugas masih sangat kurang. Terlihat hanya beberapa siswa saja yang aktif sedangkan siswa yang lain hanya diam dan menunggu hasil pekerjaan temannya.

3. Pada kegiatan investigasi masih ada beberapa anggota kelompok yang kurang berkontribusi pada kelompoknya.

4. Sebagian besar siswa mengeluh kesulitan dalam mengerjakan soal tes akhir siklus, hal ini bukan dikarenakan soalnya yang terlalu sulit. Tetapi, memahami maksud soal saja mereka masih kesulitan, tentu saja mereka akan kesulitan untuk menyelesaikan atau mencari solusi yang tepat.

5. Ketika siswa diberikan soal-soal matematika, mereka tidak terbiasa berpikir tentang apa yang diketahui, apa yang dicari, bagaimana cara mencari solusi, hingga untuk menemukan jawaban yang tepat. Hal ini berakibat bahwa soal-soal matematika terkesan sangat sulit.

6. Kurang tepatnya peneliti dalam memperkirakan waktu yang direncanakan, sehingga pada pertemuan pertama waktu pembelajaran melebihi jam yang direncanakan yaitu sekitar 15 menit pada saat kegiatan diskusi kelompok.

Dari hasil refleksi pada siklus I ini, dapat diketahui bahwa masih banyak kekurangankekurangan pada pelaksanaan siklus I, hal ini menunjukkan bahwa hasil pelaksanaan siklus I ini masih belum sesuai dengan yang diharapkan. Untuk itu, kekurangan-kekurangan tersebut perlu diperbaiki pada siklus II. Dilihat dari hasil evaluasi siklus II ini meningkat dari siklus I, dimana pada siklus II hasil rata-rata kompetensi belajar siswa adalah 70,3 artinya pada siklus II meningkat 7,6. Sehingga berdampak pada ketuntasan belajar secara klasikal dengar persentase $89 \%$. 
Berdasarkan hasil observasi yang diamati pada siklus II ini menunjukkan bahwaaspekaspek persentase keterlaksanaan pembelajaran dengan model pembelajaran kooperatif tipe group investigationsudah berkagerori aktif untuk kegiatan siswa dan aktivitas gurunya berkategori baik. Setelah melihat uraian data di atas, maka dapat disimpulkan bahwa proses pembelajaran pada siklus II telah mencapai indikator keberhasilan dalam penelitian sehingga penelitian ini dihentikan.

\section{KESIMPULAN}

Berdasarkan hasil analisa data dan pembahasan, maka dapat disimpulkan bahwa penerapan model pembelajaran kooperatif tipe group investigation pada materi sistem koordinat dapat meningkatkan kompetensi belajar matematika siswa kelas VIIIA SMP Negeri 2 Manggelewe. Hal ini dapat dilihat dari nilai rata-rata kompetensi belajar siswa 66,3 dengan persentase ketuntasan belajar sebesar 71,4 dan pada siklus yang ke dua nilai rata-rata kompetensi siswa menjadi 70,3 dengan persentase ketuntasan belajar siswa $89 \%$.

Penerapan model pembelajaran kooperatif tipe group investigation pada materi sistem koordinat dapat meningkatkan aktivitas belajar siswa dan aktivitas mengajar guru. Hal ini dapat dilihat dari peningkatan aktivitas siswa dan guru dari masing-masing tiap siklus yaitu aktivitas siswa dari kategori cukup aktif menjadi aktif dan aktivitas guru dari kategori cukup baik menjadi baik.

\section{REKOMENDASI}

Hasil penelitian ini untuk menembah referensi guru-guru matematika dalam pelaksanaan model pembelajaran matematika dan juga untuk bahan referensi peneliti selanjutnya.

\section{UCAPAN TERIMAKASIH}

Ucapan terimakasih kepada bapak kepala sekolah, guru-guru, dan siswa-siswa di SMPN Manggelewa yang telah membantu dalam proses pelaksanaan penelitian.

\section{REFERENSI}

Arends, R.I \& Kilcher, A. (2010). Teaching for student learning "becoming an accumplhised teacher”. New York: Published in the Taylor \& Francis e-Library.

Depdiknas. (2003). Peraturan Menteri No 20 Tahun 2003, Tentang Sistem Pendidikan Nasional 
Douglas, F., Frey, N., \& Eferlove, S. (2009). Productive group work. Scott Willis: ASCD Alexandria, Virginia USA

Johnson \& Halubec. (2010). Colaborative learning. (penerjemah Narulita Yusron). Nusa media: Bandung

Knight, J. (2009). Cooperative learning. http//www.instructionalcoach.org. diaskes tanggal 12 Januari 2017 